[Article copies available for a fee from The Transformative Studies Institute. E-mail address: journal@transformativestudies.org Website: http://www.transformativestudies.org (C2010 by The Transformative Studies Institute. All rights reserved.]

\title{
Introduction New Essays for a New Century
}

\author{
Jay Corwin ${ }^{1}$
}

During the seventies and eighties, academic articles tended to cling to models of reception offered by French critical theory and, to a lesser extent, by Russian formalism and Saussurian linguistics. Rarely now does one hear of the signifier and signified, surveillance, polyglossia. In that era, an article about a work of literature may have been a threnody of tightly strung neologisms, questions posed but left unanswered or hinted at through quotations by popular cultural theorists. Clarity of thought had been supplanted by sonorous jargon. The Prufrock peach that critical analysis had become was momentary; a breaking away from an earlier, rigid and sometimes starchy means of interpretation, but the new model had later become rigid and uninviting.

$21^{\text {st }}$ century visions of literature are perceived through eyes that have witnessed the fall of the Berlin Wall, the shrinking of the ozone layer, global warming, and the resultant generational move away from the self towards a collective consciousness. Reactions to the postmodernist vision of arts and culture were varied. Stanislaw Lem's 1974 dissection of Tzvetan Todorov's theory of Fantastic Literature is one example ${ }^{1}$ of dissatisfaction with theories generated mainly by the French. Victor

\footnotetext{
${ }^{1}$ Jay Corwin, Ph.D., is Senior Lecturer of Spanish at the University of Waikato in Hamilton, New Zealand. He received his Ph.D. in Spanish from Florida State University in 1995. His first book was La transposición de fuentes indígenas en Cien años de soledad [The Transposition of Indigenous Sources in One Hundred Years of Solitude], (Romance Monographs number 52, 1997). He recently gave a keynote presentation at an international conference in Lima, Peru, to mark the fortieth anniversary of the publication of One Hundred Years of Solitude. His recent publications include articles about the works of Gabriel García Márquez, Juan Rulfo and other contemporary Latin American novelists. He is currently working on a book about myth in the novels of Gabriel García Márquez, and editing a volume of essays on One Hundred Years of Solitude for Rodopi Press's Dialogue Series.
} 